\title{
基于生态系统服务供需的厦漳泉地区 生态网络空间优化
}

\author{
胡其玉 ${ }^{1,2}$, 陈松林 ${ }^{1,2}$ \\ （1. 福建师范大学,福建省亚热带资源与环境重点实验室,福州 350007; \\ 2. 福建师范大学地理研究所, 福州 350007)
}

\begin{abstract}
摘要: 耦合生态系统服务供需和景观生态安全格局, 解构城市群地区生态空间结构, 是优化农 业一城镇一生态网络空间布局的基础。基于生态系统服务供需理论, 以福建东南沿海厦漳泉 城市群为例, 综合生态系统服务最重要区域和生态红线边界确定供给源地, 结合自然、经济多 要素构建消费格局, 应用最小累积阻力模型建立景观生态安全格局, 识别需求分区、生态流网 络、关键节点等组分, 采用分层叠加分析重构厦漳泉地区生态网络空间。结果显示: (1)供给源 地占研究区总面积的 $41.64 \%$, 生态缓冲区、生态敏感区和生产生活区分别占 $22.67 \%$ 、31.58\%和 $4.11 \%$; (2) 供给源地集中于中西部丘陵山区, 耗费低值区与供给源地分布一致, 而高值区呈 “井”字形分布特征, 集中于沿海一带; (3)生态流通道网状化程度较高, 中西部主要由森林构 成, 东部沿海区域主要由城镇水系和绿地系统、周边农田构成, 驱动因素类型和强度均呈现显 著的空间异质性; (4)提出构建厦漳泉地区“九区四组团一带九廊道多中心”的生态网络空间优 化布局,协调区域间生产生活生态功能组合,促进经济一生态空间协同发展。
\end{abstract}

关键词：生态系统服务;生态网络空间;最小累积阻力模型;厦漳泉地区

伴随城镇化的普及和成熟，人口集中、社会经济资源集聚的城市群地区已成为人类 生产生活的核心场所，土地利用和经济建设的强化使得对生态系统服务 (Ecosystem Services, ES）的获取愈加强烈, 引发生态系统原有结构和功能转变而出现生态系统服务供 需失衡 ${ }^{[1]}$ 。生态系统服务供需关系受自然环境、城市格局、人口结构等自然和人文因素的 综合影响 ${ }^{[2]}$, 因而需要根据城市群实际情况对其展开综合评估 ${ }^{[3]}$ 。依托 RS 和 GIS 技术，考 虑自然环境压力和社会资源胁迫，判别生态系统和人类社会间服务流动的路径和网络关 键节点, 将生态系统服务供需理论融人生态网络空间的构建，以生态网络空间优化构筑生 态安全屏障, 在诊断区域生态环境关键问题、筛选障碍因素、厘清生态过程等方面促进 国土生态修复，从而塑造生态产品与服务供需均衡的国土空间开发格局，既有益于推进 基于生态底线的城市群地区国土空间规划探索，又益于拓展生态系统服务流研究的应用。

生态系统服务供需与生态安全格局的耦合是城市群生态问题研究的热点 ${ }^{[4]}$, 但当前关 于供需关系的解析不够深人 ${ }^{[[]}$, 多数集中于理论探讨, 而在区域实际应用中还存在理论基 础不牢的问题 $[$ [ $\mathrm{ES}$ 供需网络是域内物质流、能量流和物种流动态变化形成的，由此引

收稿日期：2019-05-30; 修订日期：2019-07-24

基金项目：国家自然科学基金项目（41771136）；福建省科技重大专项（2012NZ0002）

作者简介：胡其玉（1993-), 男, 四川成都人, 硕士, 主要从事土地利用评价方面研究。

E-mail: zhongguo999long@qq.com

通讯作者：陈松林（1964-)，男，福建南安人，博士，教授，主要从事土壤地理与土地资源研究。

E-mail: slchen6@163.com 
发供需空间的异质性 ${ }^{[7]}$, 需要开展 ES 空间流动的分布格局研究 ${ }^{[8,9]}$; 生态流即为景观组分间 物质、能量、物种的空间流动 ${ }^{[10]}$; 供需区实则为生态系统功能、服务与景观格局耦合 ${ }^{[11]}$ 的结果。而生态系统服务流是供需研究的进一步深化 ${ }^{[12]}$, 是人类社会与自然环境联系的 纽带, 在地质地貌、土地覆被、人类活动的作用下，借助水流、气流、人类活动路径等 向外传输服务，在此过程中，产生实际消费（原料、粮食等）和潜在消费（土壤保持、 水文调节等） ${ }^{[13]}$ 。从景观格局角度出发，廊道作为生态系统服务流的通道，与流之间交 互作用形成特定区域的空间网络结构 ${ }^{[14]}$ 。目前，应用InVEST 模型、贝叶斯网络分析、根 据土地覆被变化建立供需矩阵 ${ }^{[15]}$ 等方法开展供需关系的研究, 或未考虑生态系统服务供 需及评价因子的空间错位 ${ }^{\left[{ }^{[16]}\right.}$ 及其因果联系而出现较大偏差, 或仅针对某一因子服务展 开，或主观性太强。随着空间分析和空间制图技术应用于生态系统服务供需制图 ${ }^{\left[{ }^{[1]},\right.}$, 识 别 ES 传输过程和路径成为其重要内容, 但对需求区制图尚待改进 ${ }^{\left[{ }^{[18}\right]}$ 。就研究区域而言, 多数研究集中于小尺度 ${ }^{[19]}$ 而限制跨区域供需特征的判别, 或以行政单位为基础单元而易 忽视单元内部空间差异, ES 在城市群空间流动的研究是优化生态空间格局和提升自然资 源综合管理水平的基础 ${ }^{[20]}$ ，但目前还较为缺乏 ${ }^{[2]}$ 。

厦漳泉地区作为海西城市群核心都市区之一, 发展快速且强劲, 是人口和经济的集 聚区，但其地形多为丘陵山地，坡度较大，既存在中西部水土流失、沿海台风干旱频发 的生态环境问题，又存在人均耕地紧缺、土地资源错配、农药污染的压力。亟需以生态 空间要素为底线和基础, 识别生态修复重点区域, 优化生态系统服务供需格局, 探索 “三生” 空间协调发展模式。而有关厦漳泉地区的研究仅停留于供需分区，缺乏对区间服务 流动的阐释。本文以 “供给一流动一需求” 为理论框架, 综合人类活动、土地覆被、地 形起伏、水土保持等因素，基于最小累积阻力模型设定阈值以反映厦漳泉地区生态系统 服务供需状况和流动路径, 判别生态系统敏感区域和关键节点, 探讨内在主导驱动因子 的影响。从要素协调和空间优化角度, 采用分层叠加生态要素的方式, 构筑厦漳泉地区 生态网络空间，促进区域间经济一生态协同发展，优化农业一城镇一生态空间布局。

\section{1 研究方法与数据来源}

\section{1 研究区概况}

厦漳泉地区又被称为 “闽南金三角”, 地 处福建省东南沿海 (图 1), 东临台湾海峡, 南 靠广东潮汕地区，处于 $23^{\circ} 48^{\prime} \sim 25^{\circ} 56^{\prime} \mathrm{N} 、 117^{\circ} \sim$ $119^{\circ} 05^{\prime} \mathrm{E}$ 之间, 包含厦门、漳州和泉州 (不含 金门县）三市。属于亚热带海洋性季风气候, 水热充沛, 森林覆盖率约为 $61.22 \%$ 。地势总体 由西北山地向东南沿海地带倾斜, 地貌景观复 杂多样, 平原、山地和丘陵错落相间。境内溪 流纵横, 包含有晋江、九龙江、漳江等河流。 厦漳泉地区陆地面积约占福建省陆地面积的 $20.4 \%$, 常住人口占比为 $45.28 \%, \mathrm{GDP}$ 占全省 地区生产总值的 $47.87 \%$ 。作为沿海经济开放区

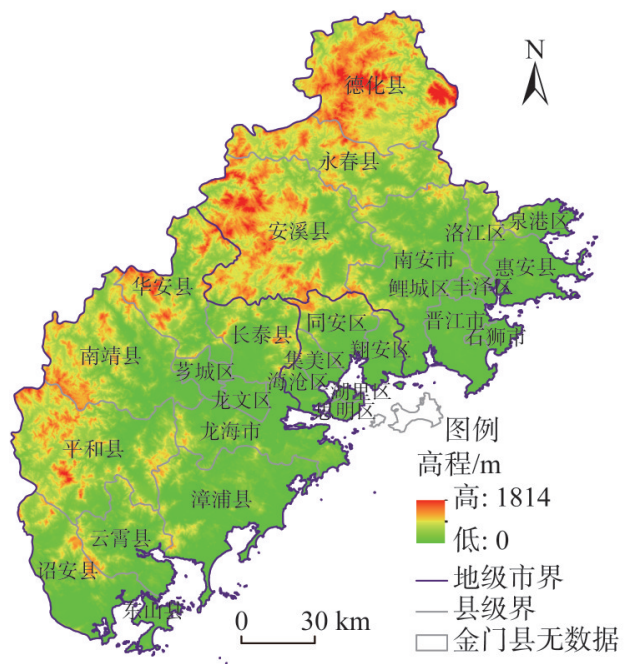

图 1 研究区区位

Fig. 1 The location of Xiamen-Zhangzhou-Quanzhou region 
之一, 具备高度融合的地域文化特征, 地区经济社会发展日益协同, 为未来统一生态区 划管理体系的建立奠定了基础。

\section{2 数据来源}

所用数据包含经济社会数据、自然环境数据及相关空间数据等。主要农作物播种面 积、单位面积产量来源于《厦门经济特区年鉴 2017》《漳州统计年鉴 2017》和《泉州统 计年鉴2017》, 主要作物平均价格依据福建省《价格检测报告》确定。2016年厦漳泉地 区 Landsat 8 遥感影像资料以及提取高程、坡度所需的GDEMDEM数据 $(30 \mathrm{~m} \times 30 \mathrm{~m})$ 来 源于地理空间数据云网站。利用 ENVI 5.1 预处理后比照 Google 地图通过人机交互判读解 译地区土地利用类型, 并参考 2017 年 $10 \mathrm{~m}$ 分辨率土地覆被图（http://data.ess.tsinghua. edu.cn/）加以比对修正。生态红线数据由福建省环保部门提供，土壤侵蚀数据源于中国 生态系统评估与生态安全数据库，河流、交通数据分别源于中国科学院资源环境数据云 和Open Street Map (OSM) 平台。多源数据统一于 ArcGIS 10.2 平台处理, 采用中国等 积圆雉投影（Albers Conic Equal Area），划分为 $500 \mathrm{~m} \times 500 \mathrm{~m}$ 基础单元展开评估。

\section{3 研究方法}

城市群自然环境、人类活动强度、公共基础设施等差异引发了生态系统服务流和供 需网络的复杂表现。从供需关系角度建立地区景观生态安全格局评估框架，实现生态系 统服务与生态过程、生态流的耦合，有利于畅通生态系统服务流动。生态系统服务供给 源（Ecosystem Service Supply Source）指生态系统服务形成和供给能力较强的主要区 域, 是人类社会获取服务的主要来源; 生态系统服务需求区（Ecosystem Service Benefit Region）指消费生态系统服务的主要区域，是各类服务的受益区；生态系统服务连接区 （Ecosystem Service Flow Area）指生态系统间能流、物流、物种流的媒介，是供给区、 需求区相互联系的桥梁和纽带 ${ }^{[2]}$ 。基于供一流一需理论识别生态系统服务源地一廊道一 汇等景观格局组分, 试图刻画生态系统服务流网络, 从而联合多影响因素建构适应地区 的生态网络空间格局。

\subsection{1 生态系统服务供给源的识别}

生态系统服务供给源为特定时间范围内能够依靠其生态完整性供给一定数量和质量 生态系统服务并对于维护地区生态系统安全不可或缺的重要区域。依据景观生态安全格 局构建方法, 参考前人研究 ${ }^{[23]}$, 选取生态系统服务价值最重要、生态敏感性较强、生态 系统较为完整的区域作为供给源地。

(1) 生态系统服务价值核算

按照谢高地等 ${ }^{[24}$ 修正 Costanza 等 ${ }^{[2]}$ 提出的生态系统服务价值评估体系, 采用时空动态 修正模型，修正单位面积生态系统服务价值当量表并完成价值评估。综合比较厦漳泉地 区种植面积大、产量高的主要农作物，采用 2016 年 $1 \mathrm{hm}^{2}$ 稻谷、甘薯、花生和蔬菜的平 均价格进行评估，并将 4 种农作物平均价格的 $1 / 7$ 作为标准单位生态系统服务价值当量因 子的价值量 ${ }^{[26]}$, 从而排除人工投人的影响。经计算, 标准生态系统的单位面积生态系统 服务价值量为 5871.72 元 $\cdot \mathrm{hm}^{-2}$ 。结合厦漳泉地区实际情况, 采用地区年均降水量因子修 正单位面积生态服务价值当量表, 修正系数为 1.90 , 测算出不同生态系统类型的价值系 数表。将不同生态系统类型的价值系数乘以其面积, 求和得到食物生产、原料生产、气 体调节、气候调节、水文调节、废物处理、土壤保持、生物多样性维持、美学景观供给 
9 种生态系统服务的总价值。运用 jenks 分级方法划分生态系统服务重要性等级为 5 级, 服务价值愈大则愈重要。

(2) 确定供给源地

考虑到生态系统服务供给源的生态系统性、生态环境敏感性，选择生态系统服务最 重要区域 $(E S V>1850.83$ 万元), 结合生态红线划定区域, 利用栅格叠加计算共同确定生 态系统服务供给源地，并剔除面积小于 $100 \mathrm{hm}^{2}$ 的细碎斑块以保证生态系统的完整性和连 续性。

\subsection{2 生态系统服务消费格局的构建}

生态系统服务消费格局即是需求区空间分布，指供给源地向其他单元扩张时，受制 于成本、技术障碍、可达性等条件 ${ }^{[27]}$, 生态系统服务在传输、转换过程便会受阻, 增加 潜在消费 ${ }^{[28]}$ 。以供给源地扩张过程生态系统服务流动阻力值的测算结果来建立阻力面, 作为人类社会使用服务以及服务扩张过程耗散的消费格局。依据生态系统服务流产生和 传递的影响因素、人类活动区域的需求程度，参考已有研究 ${ }^{[29-31]}$ 并结合研究区自然经济状 况，从自然地理、生态环境、社会资源胁迫三方面选取影响因素构建消费格局。坡度、 高程能够调控水热分配决定生态系统服务流向 ${ }^{[32]}$; 水源涵养、土壤侵蚀能直接影响生态 系统气候调节、生物多样性、土壤保持等服务; 人口负荷强度是构建以人为中心的生态 系统服务消费格局的基础，道路交通分布对于区域发展或衰落具有重要意义; 土地利用 方式是人类活动的集中体现，既是各类生态系统服务的影响因素，也是服务的重要载体。

应用层次分析法（AHP）确定所选 7种评价因子的权重，结合福建省生态功能区划 划分评价因子等级 ${ }^{[33]}$ 并设定阻力值（表 1)，阻力值愈大则供给源地扩张的耗费愈大，反 之愈小。通过ArcGIS 10.2 栅格叠加功能, 对各评价因子阻力值进行加权求和, 以表征研 究区生态系统服务消费格局。

表 1 评价因子体系及阻力系数

Table 1 Evaluation factors and resistance coefficients

\begin{tabular}{|c|c|c|c|c|c|c|c|}
\hline \multirow{2}{*}{ 评价因子 } & \multirow{2}{*}{ 单位 } & \multirow{2}{*}{ 权重 } & \multicolumn{5}{|c|}{ 阻力值 } \\
\hline & & & 10 & 30 & 50 & 70 & 90 \\
\hline 人口密度 & 人 $\cdot \mathrm{km}^{-2}$ & 0.251 & $0 \sim 50$ & $50 \sim 500$ & $500 \sim 3000$ & $3000 \sim 6000$ & $>6000$ \\
\hline 土地利用类型 & - & 0.251 & 森林、湿地、水域 & 灌木林、草地 & 耕地 & 裸地等 & 建设用地 \\
\hline 距交通干线距离 & $\mathrm{m}$ & 0.027 & $>5000$ & $2000 \sim 5000$ & $1000 \sim 2000$ & $500 \sim 1000$ & $<500$ \\
\hline 距水源涵养区距离 & $\mathrm{km}$ & 0.251 & $0 \sim 1$ & $1 \sim 3$ & $3 \sim 5$ & $5 \sim 10$ & $>10$ \\
\hline 坡度 & $\left({ }^{\circ}\right)$ & 0.054 & $0 \sim 5$ & $5 \sim 10$ & $10 \sim 25$ & $25 \sim 35$ & $>35$ \\
\hline 高程 & $\mathrm{m}$ & 0.054 & $0 \sim 200$ & $200 \sim 400$ & $400 \sim 600$ & $600 \sim 1000$ & $>1000$ \\
\hline 土壤侵蚀强度 & - & 0.114 & 微弱 & 轻度 & 中度 & 强度 & 极强和剧烈 \\
\hline
\end{tabular}

注: 森林的阻力值为 5 。

\subsection{3 景观生态安全格局的建立}

基于最小累积阻力模型（Minimum Cumulative Resistance，MCR）应用Cost Distance 分析模块，依据生态系统服务消费格局测算供给源地到其他单元的最小累积耗费， 识别生态系统服务需求分区、生态服务流、辐射流、关节点等组分，从而构建景观生态 安全格局。 
根据研究区生态维护、经济发展、社会生活等情况, 综合比较最小累积阻力值大小 与面积关系曲线的突变等方法 ${ }^{[34]}$, 采用几何间隔分级法依据最小累积阻力值低、中、高 水平，划分生态缓冲区、生态敏感区、生产生活区。

基于不确定性理论识别景观廊道 ${ }^{[3]}$ ，以沟通供给源地间物质、能量、信息流通的最 小累积阻力低谷区作为生态服务流, 具有保障生态系统整体性和连通性的重要意义; 应 用ArcGIS 10.2 水文分析模块识别以供给源地为中心向其他地方扩散生态流的最小累积阻 力谷线区，作为辐射流；生态服务流是 “源” 间潜在的生态系统服务连接区，而辐射流 是供给源地生态系统服务能动外流的连接区 ${ }^{[36]}$ 。

在以临近供给源地间等阻力切点为生态节点的基础上, 选择面临较大生态压力的区 域作为关键节点, 是实施生态维护和生态修复、保障生态系统服务连接区畅通的重要所在。

\subsection{4 基于网络构建的生态空间布局优化}

基于多要素联合构建的景观生态安全格局是生态系统服务流网络的真实表现，通过 解构组分的 “点一线一面” 空间结构，从生态系统功能完整性、区域资源空间分异、发 展现状和规划目标出发, 分层叠加生态要素, 整合山川海、林园田和城镇等自然一人文 景观，优化地区整体生态空间结构。以供给源地为地区生态安全底线，结合《福建省生 态功能区划》, 确立生态服务核心区域, 其他区域为生态基质; 依据城市精明增长和紧凑 发展理论, 参考《主体功能区划》, 以主要生产生活区作为城镇群发展组团, 控制城市无 序蔓延扩张，保障绿地和农地空间留置；沟通主要河流和道路、生态系统服务连接区以 形成生态廊道网络, 连接大陆和海岛海岸线以完善海岸生态防护带; 以关键节点作为生 态缓冲区、敏感区的生态关键中心，发挥生态枢纽作用。从而优化生态系统服务流动网 络和区域功能组合, 构筑城市群地区的生态网络空间 ${ }^{[3]}$, 促进人类经济活动与自然生态 过程的协同 ${ }^{[38]}$ 。

\section{2 结果分析}

\section{1 厦漳泉地区生态系统服务供给源地空间 格局}

经测算，厦漳泉地区生态系统服务供给 源地面积总计为 $10275.50 \mathrm{~km}^{2}$, 约占研究区总 面积的 41.64\%（图 2)。其中，生态红线划定 区域与生态系统服务最重要区域具有互补 性: 生态红线包含了水土流失等生态环境较 为敏感的区域, 而生态系统服务最重要区域 兼顾了较大斑块面积的生态源地; 两者之间 又具有高度的一致性：两者大型斑块的面积 和空间分布高度重叠, 共同形成厦漳泉地区 生态系统服务供给格局。供给源地主要沿戴 云山一博平岭山脉分布于厦漳泉中西部的丘 陵和山地, 晋江口、九龙江口、漳江口和海 岸线一带分布较少。分区统计各县（市、

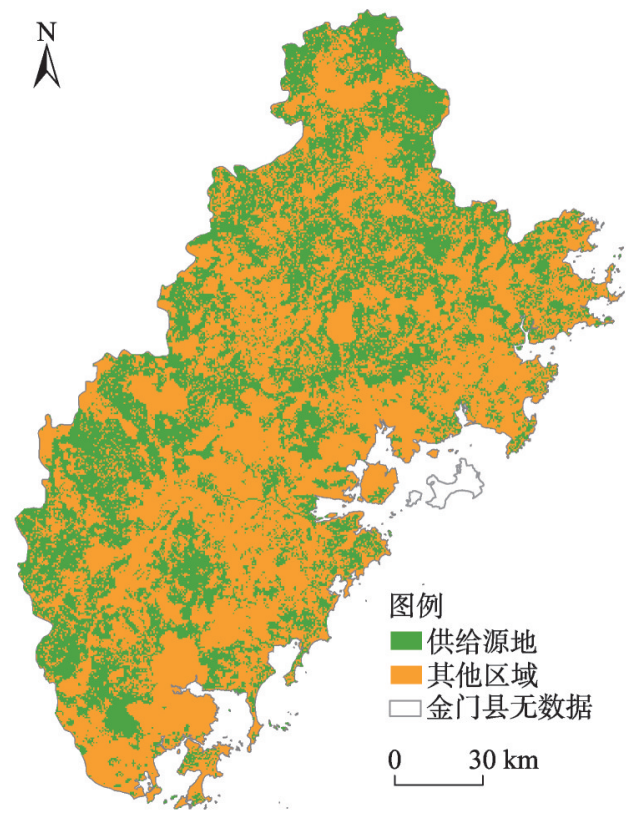

图 2 生态系统服务供给源地分布

Fig. 2 Distribution of ecosystem service supply area 
区）生态供给源地数量, 主要分布于安溪、德化、平和和南靖 4 县, 分别占供给源地比 例为 $11.99 \% 、 11.99 \% 、 11.24 \% 、 9.75 \%$ ，共达 $44.97 \%$ ，应是给予生态补偿的重点区域。

从土地利用类型看，供给源地主要由林地构成且集中分布于中西部; 耕地除少数散 布于河谷盆地外，大部分位于沿海平原地带; 而沿海地带也是水域、湿地集中分布的区 域, 对于维护海岸线生态平衡具有重要意义。从生态系统服务看, 值得注意的是, 厦漳 泉地区食物生产服务的供给能力普遍较弱，与其他服务的权衡效应较突出，主要由漳州 和泉州平原提供; 而平原区的其他服务供给能力都较其他区域低，呈现空间权衡。

\section{2 厦漳泉地区生态系统服务消费格局空间特征}

选取 7 种评价因子经栅格叠加后生成阻力面（图 3a），表征全域生态系统服务流动耗 费情况，结果显示，阻力低值区与供给源地分布具有一致性，说明临近供给源地的区域 生态系统服务流动更加顺畅，所受阻力愈小; 阻力高值区普遍为人类较活跃的区域，集 中于沿海相对平坦的平原和低丘。整体而言, 自西北向东南阻力值渐增, 生态系统服务 流动压力越大，阻力高值区呈现 “井” 字形分布特点，切断了阻力低值区的连通性。基 于最小累积阻力模型建构除供给源地外的厦漳泉地区生态系统服务消费格局（图 3b), 集聚特征愈加显著，揭示了供给源地向外扩张时面临的高压地带。阻力高峰集中在四大 区域: 泉州市东南（鲤城、晋江、石狮）、厦门市城区（湖里、集美、同安和翔安的滨海 区域）、漳州市中部（芕城和长泰县城）、漳州市南部（云霄县漳江河口）。
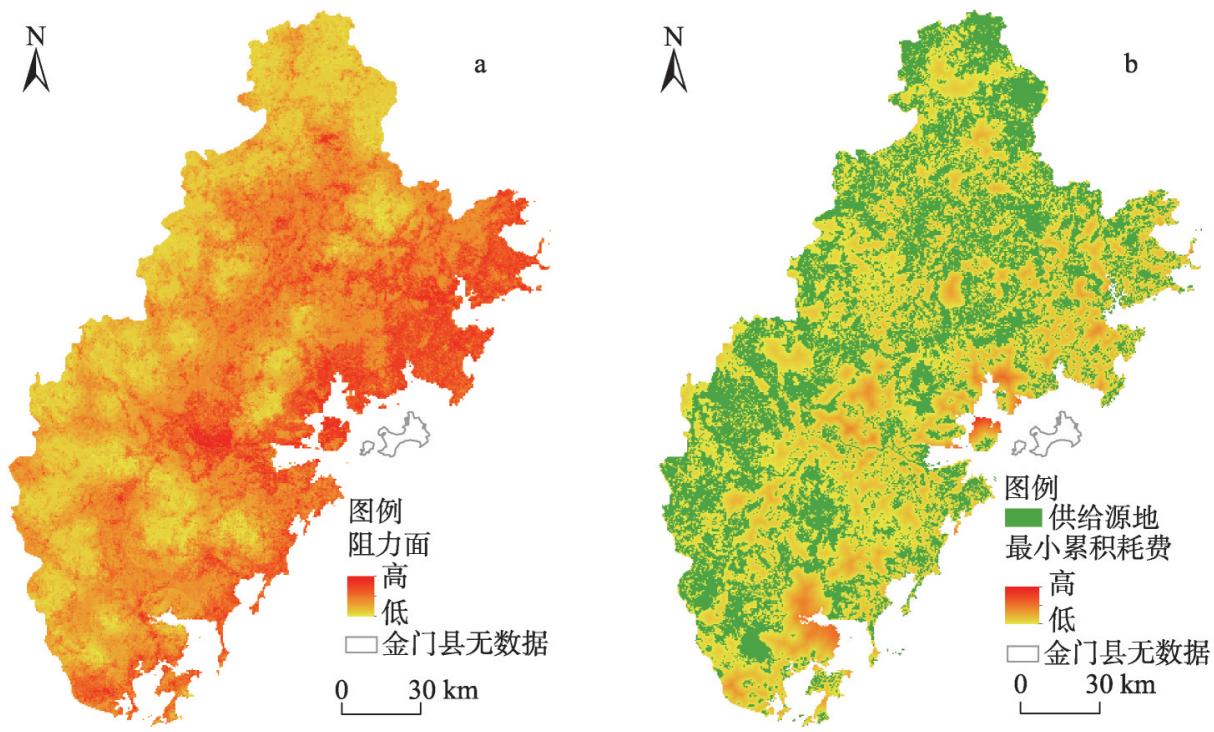

图 3 生态系统服务消费格局

Fig. 3 Pattern of ecosystem service consumption

从评价因子看，土地利用类型、人口密度、道路交通密度对生态系统服务流动的影 响具有空间一致性，是制约沿海区域、厦漳泉中心市区以及各县（市、区）城区范围内 服务流动的主导因子，土地利用程度越高、人口密度和交通路网密度越大，耗费作用越 强; 水源涵养区域与阻力低值区、供给源地均具有较高一致性, 距离其越远, 服务流动 阻力越大，呈显著的距离衰减效应。海拔是制约德化县中北部服务流动的关键因素，而 
在其他区域并不具有强耗费作用; 坡度与海 拔的影响具有空间一致性, 而坡度在更大范 围制约服务流动，受技术限制在较大坡度区 域进行农业生产而易引发生态脆弱性; 土壤 侵蚀程度较强的区域分布零散, 主要为水力 侵蚀, 受海拔、坡度影响，在丘陵和平原交 错地带、安溪中部和华安中部丘陵地带对服 务流动阻碍较大。

\section{3 厦漳泉地区景观生态安全格局构建与结构 解析}

基于生态系统服务供需空间格局，进一 步识别生态系统服务需求分区、生态服务流 和辐射流、关键节点等景观组分, 通过 “点 一线一面” 等要素叠置建立厦漳泉地区景观 生态安全格局（图 4)。

结合厦漳泉地区实际, 划分生态缓冲区 (4544.91 20010.27)、生态敏感区（20010.27 105427.93）、生产生活区（105427.93 577203.17）三类生态功能需求分区，面积分

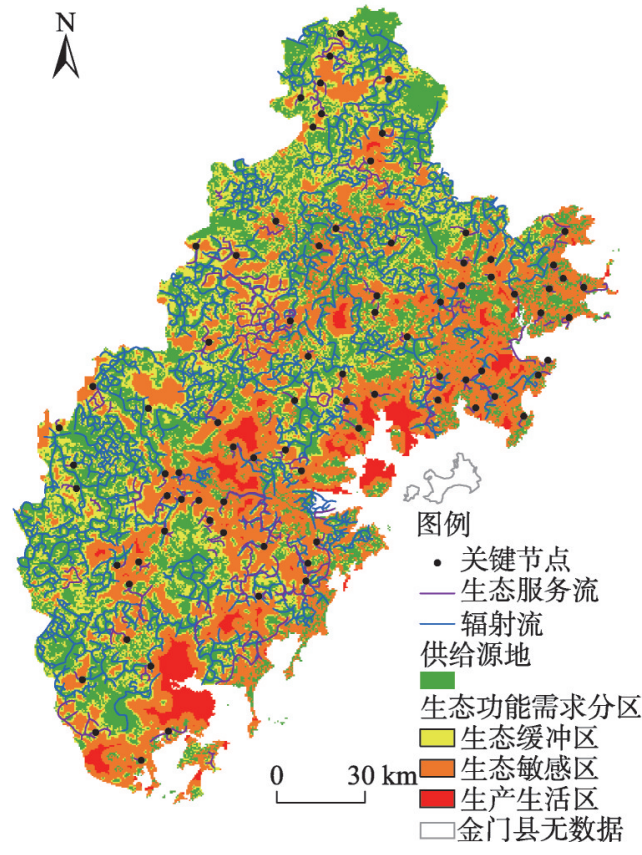

图4 厦漳泉地区景观生态安全格局

Fig. 4 Landscape ecology security pattern in Xiamen-Zhangzhou-Quanzhou region 别为 $5593.17 \mathrm{~km}^{2} 、 7793.67 \mathrm{~km}^{2} 、 1013.67 \mathrm{~km}^{2}$, 约占研究区总面积比例分别为 $22.67 \%$ 、 $31.58 \%$ 、 $4.11 \%$ 。生态缓冲区紧临供给源地分布，作为供给源地的延伸部分，是次一级的 生态系统服务供给源地，应管制该区域的人类开发活动以避免造成难以恢复的生态破 坏。生态敏感区处于人类频繁活动区域与供给源地之间，既是人类生产生活扩展的潜力 区，也是维护生态环境健康的关键区，作为生态系统服务能力优化与人类开发建设间矛 盾较集中的区域，应因地制宜，适度开发，避免如陡坡垦殖等问题。生产生活区主要为 厦漳泉地区地势较平坦、人口集聚的中心市区和县城，是人类社会对生态系统服务需求 最大的区域。值得注意的是，云霄县漳江河口区域经济社会欠发达，又因人类活动与自 然环境的不协调而面临较大生态压力，故应针对土壤侵蚀等问题加强生态基础设施建设 和修复，通过升级产业结构、调整生产方式协调区域内经济发展优势、人口特征、用地 结构等要素，形成区域生态修复与经济建设协同共进的发展模式 ${ }^{[39]}$ 。

识别廊道作为生态系统服务连接区，根据其性质，区别生态服务流和辐射流：生态 服务流通道 97 条, 总长 $1523.32 \mathrm{~km}$; 辐射流通道 65 条, 总长 $5884.17 \mathrm{~km}$ 。两者共同沟通 着供给源地之间、供需区之间，维持厦漳泉地区生态系统服务整体的流通性。目前，地 区生态系统服务外流情况趋于良好，生态系统服务供给能力较强，且服务流扩展潜力充 足，局部区域存在阻断现象。从空间分布看，受供需区分布影响，生态服务流通道多分 布于东部沿海，少数处于中西部生态阻力较强的区域，其中安溪县西南部密度较大; 而 辐射流大部分位于海拔较高的中西部，东部沿海较为稀疏; 两者构成地区的廊道网络系 统。从影响因素看，适度的海拔和坡度有益于生态系统服务流通和物种迁移; 而人口密 
集区域则难以建立流通通道; 中西部城镇以外区域服务流通道的建立依赖于森林系统的 完整性，而在城镇区域服务流通道是由综合的复杂体系构成，一是生态价值巨大的滨江 滨海湿地和城镇内外部水系, 二是城镇内部的绿地系统（主要是由灌木、草地组成）, 三 是城镇周边的农田（覆盖绿植的农田是建立服务流通道的重要组成）。从形状结构看，生 态服务流和辐射流均呈曲折的分支形网络结构和不规则形网络结构，相互间重叠、联 通、阻断的情况并存; 供给源地间一般为短距离通道, 缩短了传输的时间, 减少了服务 流通的损耗; 通道具有较大弯曲度, 能够创造更多的异质环境, 有益于提高通道内的物 种丰富度。此外，海岛（厦门岛、东山岛）和狭长的半岛（六鳌半岛、古雷半岛等）因 其空间独立性较难形成生态系统服务流通道，应控制区域内开发强度，修复海岸带生态 环境，维持生物多样性。

关键节点是维持生态系统服务流通相对困难的重要所在。厦漳泉地区关键节点确定 有 92 处, 整体分布比较均匀。从影响因素看, 坡度影响作用强于海拔, 关键节点的分布 多集中于土壤侵蚀较强的区域，且临近道路交通。因而，针对这些区域，一是避免开发 建设项目接近，二是加强土地生态工程建设，综合物理、生物、耕作措施建立农田下 川、坡顶成林的立体优化结构，三是结合当地生态系统建设森林路网或者架构生态桥梁 等, 改善生境。总之, 关键节点所在通常为生态交错带, 即景观中环境因素（坡度、侵 蚀强度等) 呈现梯度渐变结构, 生态环境异质性和敏感性较强 ${ }^{[00]}$, 需要重点监测和维护。

在建立厦漳泉地区景观生态安全格局的基础上，完善自然生态廊道，保育人工一自 然生态廊道，衔接局部区域生态需求分区和关键节点，服务生态一经济系统整体。

\section{4 厦漳泉地区生态网络空间优化}

依托山水、林草、园田、城镇等基本要素，以生态系统服务功能分区为布局基础，以 生产生活核心区域为城镇群发展组团, 以大 陆、海岛海岸线构成的海岸生态防护带和以河 流、道路交通、生态系统服务连接区构成的廊 道网络连接农业、城镇、生态空间, 以关键节 点为功能分区、城镇和廊道之间的枢纽, 形成 厦漳泉地区 “九区四组团一带九廊道多中心” 的生态网络空间优化布局方案（图 5)。

具体方案如下（表2):

依据生态系统服务功能的差异, 将 “九 区” 划分为生态保育核心区与水土流失敏感 区、生态一农业交错区、城郊集约农业区，分 别处于地区的西、中、东段。西北部和西南部 水源涵养与生态保育区、中部水土流失敏感区 主要沿戴云山一博平岭大山带分布, 以水源涵 养为核心并融合物种多样性保护、水土保持、 美学景观等形成综合生态系统服务供给体系, 应限制开发建设, 治理水土流失、农业污染等

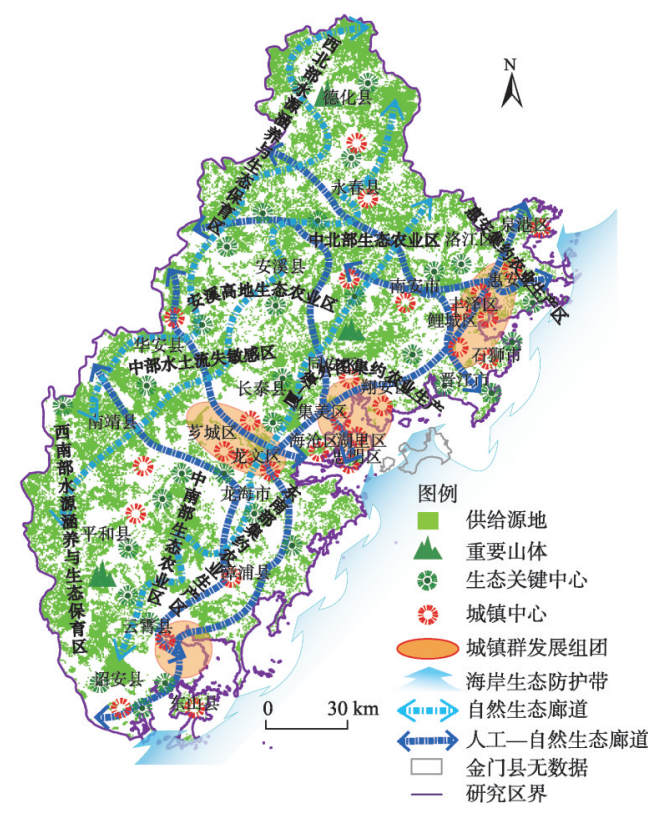

图 5 厦漳泉地区生态网络空间优化布局方案

Fig. 5 Optimizing the spatial arrangement of ecological networks in Xiamen-Zhangzhou-Quanzhou region 
表 2 “九区四组团一带九廊道多中心”生态网络空间优化说明

Table 2 Interpretation of "nine zones, four groups, one belt, nine corridors and multi-centers"

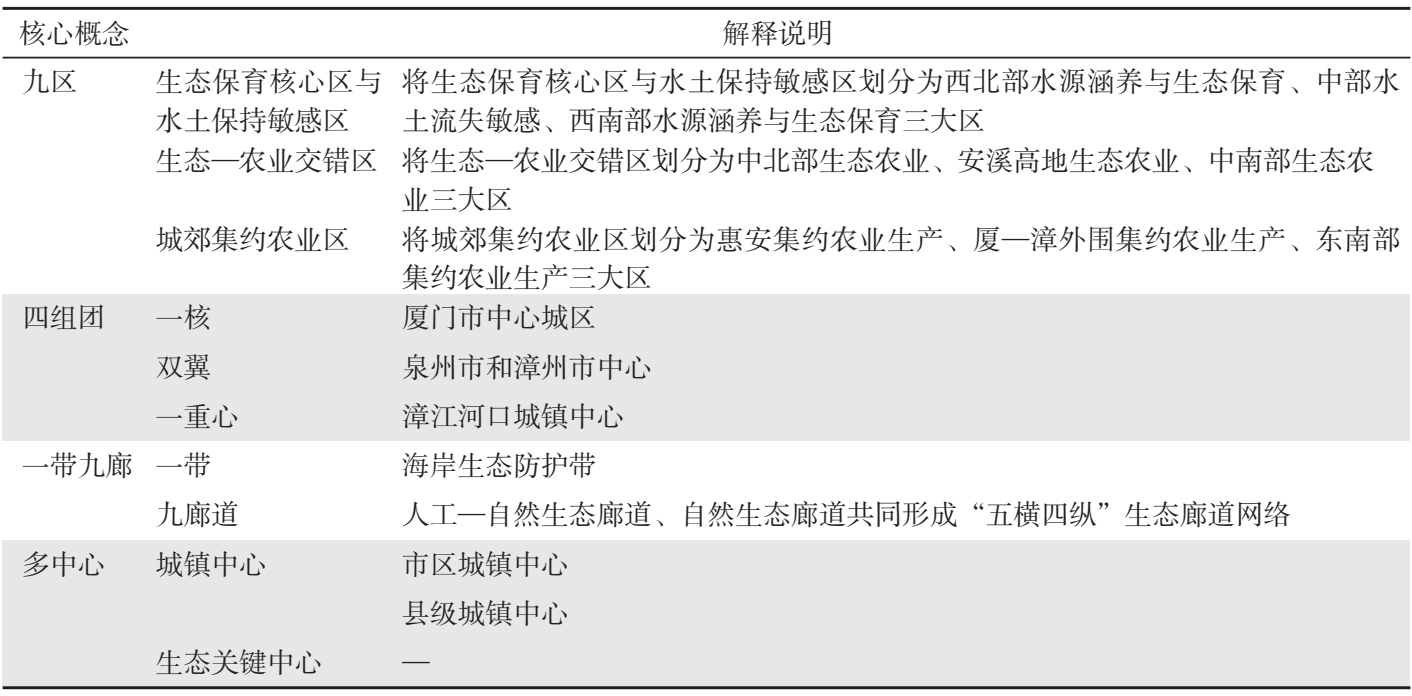

问题，管护矿区森林生态系统，继续强化生态修复工程。中北部、安溪高地、中南部生 态农业区主要沿永春一诏安丘陵山区一带分布，以土壤保持为核心并融合茶果农产品供 给形成生态一农业交互区，应发展生态农业以减少污染，避免坡地开艮以防止水土流 失, 养护森林生态系统以维持原材料服务供给。东部集约农业生产区分布于沿海城镇附 近的台地和平原，是结合工农业供给多样化产品的城镇经济拓展区域，集约化程度高， 以供给生态、农业产品服务为核心的同时应融人城市生态环境综合管理体系，推进城乡 间生产生活生态协调发展。

依据城镇化集聚程度和区域带动能力，将“四组团”划分为“一核双翼一重心”的 城镇群空间组织结构, 分解厦漳泉城市群建设于具体城镇中心，以人工一自然廊道为轴 线沟通各个组才。串联厦门市各个城镇中心，拓展中心城区范围转向海湾型城市发展模 式, 推进岛内外经济一生态一体化建设, 扩大特区的龙头带动作用; 以泉州民营工业体 系和漳州生态农业优势为区域发展基础, 加强泉州中心市区与晋江、石狮的区域协调, 促进漳州中心市区和外围开发区集聚，形成工业一农业一生态一文化复合的现代化宜居 城市, 增强区域集聚和辐射能力; 以云霄县漳江河口城镇中心为（漳）浦一云（霄）诏（安）一东（山）区域枢纽重点，打造厦漳泉地区经济一生态协同发展第四极。

依据海湾、海岛等海岸线要素和交通道路干线分布，联合生态服务流、辐射流，形 成 “一带九廊” 的生态网络系统。海岸带既是环境变化敏感又是经济和人口集聚的区 域, 因而有必要管控海岸带生态和港口建设格局, 维护海洋生物多样性, 提升海岸带防 护功能。交通干线一般与河流、山谷线保持一致，以泉南、厦蓉、沈海、厦沙等高速和 漳泉、鹰厦、龙厦、福厦、厦深等铁路及晋江、九龙江等主要河流为骨干，形成人工一 自然生态交互廊道; 以生态服务流、辐射流连接生态功能分区，沟通各区之间物质、能 量、信息交流, 形成自然生态廊道; 从而实现人工廊道与自然环境的有机融合, 构筑厦 漳泉地区 “五横四纵” 生态廊道网络体系, 形成生态一农业一城镇空间互通的格局，促 
进人与自然、城镇的和谐统一。

以人口、经济相对集聚的城镇中心和贯通生态廊道的关键节点作为经济一生态协同 推进的关键中心，形成经济一生态 “多中心” 发展格局。其中，处于城镇群组团区域的 为市区城镇中心，其他的为县级城镇中心，依托人工一自然廊道促使城镇群组团辐射和 带动县级城镇中心向生态化、特色化宜居城镇发展; 而生态关键中心大多位于生态廊道 或城镇中心附近，具有衔接生态功能分区、生态廊道间的作用，是生态建设和修复的重 点管控区域。

\section{3 结论与讨论}

\section{1 结论}

应用景观生态安全格局构建方法探讨综合生态系统服务供需区划和连接区识别，分 层叠加生态要素，完善生态廊道系统以优化厦漳泉地区生态网络空间。主要结论为:

(1) 从数量关系看, 地区生态系统服务供给源地面积为 $10275.50 \mathrm{~km}^{2}$, 约占研究区 面积的 $41.64 \%$; 生态缓冲区、生态敏感区、生产生活区三类生态功能需求分区占地区总 面积比例分别为 $22.67 \% 、 31.58 \% 、 4.11 \%$; 生态服务流通道 97 条，辐射流通道 65 条，总 计 $7405.49 \mathrm{~km}$; 关键节点共计 92 处。

（2）从空间分布看，供给源地集中于中西部丘陵山区，不仅为 ES 供给的核心区域, 也包含生态敏感区; 阻力值自西北向东南渐增, 阻力低值区与供给源地分布一致, 而高 值区呈 “井” 字形分布特征; 生态缓冲区紧临供给源地可补充生态系统服务供给，生态 敏感区是生态系统功能维持与人类开发建设矛盾较大的区域，生产生活区主要为生态系 统服务需求巨大的中心市区和县城; 虽均为生态系统服务连接区, 生态服务流主要分布 于东部沿海，辐射流却集中于中西部; 关键节点整体上均匀地分布全区，多位于生态交 错带。

（3）从驱动因素看，供给源地主要由林地构成; 生态功能需求分区由生态系统服务 供需格局共同确定，大部分区域土地利用程度越高、人口密度和交通路网密度越大，则 服务流动耗费越大，较大坡度的局部区域叠加农业生产活动后呈生态脆弱表现; 低丘缓 坡地形有益于而人口密集分布则会阻碍服务流通道的建立, 地区中西部通道主要由森林 构成, 而城镇区域通道主要由城镇水系和绿地系统、周边农田构成; 关键节点受土壤侵 蚀和道路交通分布影响较大。

（4）以生态保育、组团发展、网络联通为原则，解构生态要素空间位置和联系特 征, 提出 “九区四组团一带九廊道多中心” 的厦漳泉地区生态网络空间优化布局方案, 促进局部区域间经济一生态协同发展。

\section{2 讨论}

目前，鲜见依据生态系统服务供需理论构建厦漳泉地区生态网络空间的研究，本文 也仅是从空间格局角度出发初探生态系统服务流网络及其应用，而关于定量刻画供需结 构匹配、生态系统服务流速流量和时空动态演变的问题有待深人，此外，所提优化方案 注重地区整体性布局优化，而对接更大范围城市群以及谋划局部区域功能等还需进一步 探索。一方面, 不同利用类型土地所供给的生态服务分类尚需完善, 随着用地类型转变 
服务类型亦会随之改变, 产生不确定性 ${ }^{[41]}$, 限制了生态系统服务价值评估结果在城市群 生态空间规划方面的应用; 另一方面，制约服务流通的关键因子的种类及限制性强度均 具有显著空间异质性，在戴云山区域海拔为制约服务流通的关键因子，在龙海、漳浦交 界处关键制约因子则是坡度与水力侵蚀，在华安、南靖交界处的强阻碍表现则是各因子 综合作用的结果，因而在一定经济技术条件下，有必要针对不同区域的强限制性的因子 设定具体开发项目的类型和强度，同时加强综合承载力评价应用，结合生态修复工程推 动人类活动迁出生态敏感区域。

不同分区间往往存在自然生态空间多重功能的交错和重合 ${ }^{[42]}$, 生态一农业、农业一 城镇交错区域既是衔接不同功能空间的缓冲区，也是生态过程变化的敏感区，应通过主 导因子的适宜性评价和综合承载力评估完善空间发展、建设分区的质量标准。此外，一 些生态脆弱区也是经济发展相对滞后的区域，从生态补偿角度出发，是补偿的盲区所 在，应作为推进经济一生态协同建设的重点示范区。

\section{参考文献(References):}

[1] 景永才, 陈利顶, 孙然好. 基于生态系统服务供需的城市群生态安全格局构建框架. 生态学报, 2018, 38(12): 41214131. [JING Y C, CHEN L D, SUN R H. A theoretical research framework for ecological security pattern construction based on ecosystem services supply and demand. Acta Ecologica Sinica, 2018, 38(12): 4121-4131.]

[2] SCHIRPKE U, CANDIAGO S, VIGL L E, et al. Integrating supply, flow and demand to enhance the understanding of interactions among multiple ecosystem services. Science of the Total Environment, 2019, 651(1): 928-941.

[3] HAO H, CHEN B, MA Z, et al. Assessing the ecological security of the estuary in view of the ecological services: A case study of the Xiamen Estuary. Ocean \& Coastal Management, 2017, 137: 12-23.

[4] 彭保发, 郑俞, 刘宇. 耦合生态服务的区域生态安全格局研究框架. 地理科学, 2018, 38(3): 361-367. [PENG B F, ZHENG Y, LIU Y. Coupling ecosystem services and regional ecological security pattern. Scientia Geographica Sinica, 2018, 38(3): 361-367.]

[5] OUYANG Z, ZHENG H, XIAO Y, et al. Improvements in ecosystem services from investments in natural capital. Science, 2016, 352(6292): 1455-1459

[6] 马琳, 刘浩, 彭建, 等. 生态系统服务供给和需求研究进展. 地理学报, 2017, 72(7): 1277-1289. [MA L, LIU H, PENG J, et al. A review of ecosystem services supply and demand. Acta Geographica Sinica, 2017, 72(7): 1277-1289.]

[7] KHAN I, ZHAO M, KHAN S U, et al. Spatial heterogeneity of preferences for improvements in river basin ecosystem services and its validity for benefit transfer. Ecological Indicators, 2018, 93: 627-637.

[8] COSTANZA R. Ecosystem services: Multiple classification systems are needed. Biological Conservation, 2008, 141(2): $350-352$.

[9] 肖玉, 谢高地, 鲁春霞, 等. 基于供需关系的生态系统服务空间流动研究进展. 生态学报, 2016, 36(10): 3096-3102. [XIAO Y, XIE G D, LU C X, et al. Involvement of ecosystem service flows in human wellbeing based on the relationship between supply and demand. Acta Ecologica Sinica, 2016, 36(10): 3096-3102.]

[10] 曾辉, 陈立顶, 丁圣彦. 景观生态学. 北京: 高等教育出版社, 2017: 107-132. [ZENG H, CHEN L D, DING S Y. Landscape Ecology. Beijing: Higher Education Press, 2017: 107-132.]

[11] 任志远, 刘炎序. 基于价值量的区域生态安全评价方法探索: 以陕北能源区为例. 地理研究, 2013, 32(10): 17711781. [REN Z Y, LIU Y X. Exploring the regional ecological security evaluation methods based on values: A case study in the energy region of Northern Shaanxi. Geographical Research, 2013, 32(10): 1771-1781.]

[12] SERNA-CHAVEZ H M, SCHULP C J E, VAN BODEGOM P M, et al. A quantitative framework for assessing spatial flows of ecosystem services. Ecological Indicators, 2014, 39: 24-33.

[13] 甄霖, 刘雪林, 魏云洁. 生态系统服务消费模式、计量及其管理框架构建. 资源科学, 2008, 30(1): 100-106. [ZHEN L, 
LIU X L, WEI Y J. Consumption of ecosystem services: Models, measurement and management framework. Resources Science, 2008, 30(1): 100-106.]

[14] FANG X, ZHAO W, FU B, et al. Landscape service capability, landscape service flow and landscape service demand: A new framework for landscape services and its use for landscape sustainability assessment. Progress in Physical Geography, 2015, 39(6): 817-836.

[15] 武爱涁, 赵艳霞, 沈会涛, 等. 京津冀区域生态系统服务供需格局时空演变研究. 生态与农村环境学报, 2018, 34 (11): 968-975. [WU A B, ZHAO Y X, SHEN H T, et al. Spatio-temporal pattern evolution of ecosystem service supply and demand in Beijing-Tianjin-Hebei region. Journal of Ecology and Rural Environment, 2018, 34(11): 968-975.]

[16] MEHRING M, OTT E, HUMMEL D. Ecosystem services supply and demand assessment: Why social-ecological dynamics matter. Ecosystem Services, 2018, 30: 124-125.

[17] PULIGHE G, FAVA F, LUPIA F. Insights and opportunities from mapping ecosystem services of urban green spaces and potentials in planning. Ecosystem Services, 2016, 22: 1-10.

[18] HEGETSCHWEILER K T, DE VRIES S, ARNBERGER A, et al. Linking demand and supply factors in identifying cultural ecosystem services of urban green infrastructures: A review of European studies. Urban Forestry \& Urban Greening, 2017, 21: 48-59.

[19] BALZAN M V, CARUANA J, ZAMMIT A. Assessing the capacity and flow of ecosystem services in multifunctional landscapes: Evidence of a rural-urban gradient in a Mediterranean small island state. Land Use Policy, 2018, 75: 711725.

[20] 方创琳, 周成虎, 顾朝林, 等. 特大城市群地区城镇化与生态环境交互耦合效应解析的理论框架及技术路径. 地理学 报, 2016, 71(4): 531-550. [FANG C L, ZHOU C H, GU C L, et al. Theoretical analysis of interactive coupled effects between urbanization and eco-environment in mega-urban agglomerations. Acta Geographica Sinica, 2016, 71(4): 531550.]

[21] BARÓ F, PALOMO I, ZULIAN G, et al. Mapping ecosystem service capacity, flow and demand for landscape and urban planning: A case study in the Barcelona Metropolitan region. Land Use Policy, 2016, 57: 405-417.

[22] BAGSTAD K J, VILLA F, BATKER D, et al. From theoretical to actual ecosystem services: Mapping beneficiaries and spatial flows in ecosystem service assessments. Ecology and Society, 2014, 19(2): 64, Dio: 10.5751/ES-06523-190264.

[23] 杨姗姗, 邹长新, 沈渭寿, 等. 基于生态红线划分的生态安全格局构建: 以江西省为例. 生态学杂志, 2016, 35(1): 250-258. [YANG S S, ZOU C X, SHEN W T, et al. Construction of ecological security patterns based on ecological red line: A case study of Jiangxi province. Chinese Journal of Ecology, 2016, 35(1): 250-258.]

[24] 谢高地, 张彩霞, 张雷明, 等. 基于单位面积价值当量因子的生态系统服务价值化方法改进. 自然资源学报, 2015, 30 (8): 1243-1254. [XIE G D, ZHANG C X, ZHANG L M, et al. Improvement of the evaluation method for ecosystem service value based on per unit area. Journal of Natural Resources, 2015, 30(8): 1243-1254.]

[25] 谢高地, 甄霖, 鲁春霞, 等. 一个基于专家知识的生态系统服务价值化方法. 自然资源学报, 2008, 23(5): 911-919. [XIE G D, ZHEN L, LU C X, et al. Expert knowledge based valuation method of ecosystem services in China. Journal of Natural Resources, 2008, 23(5): 911-919.]

[26] LOOMIS J, KENT P, STRANGE L, et al. Measuring the total economic value of restoring ecosystem services in an impaired river basin: Results from a contingent valuation survey. Ecological Economics, 2004, 33(1): 103-117.

[27] 刘慧敏, 刘绿怡, 丁圣彦. 人类活动对生态系统服务流的影响. 生态学报, 2017, 37(10): 3232-3242. [LIU H M, LIU L Y, DING S Y. The impact of human activities on ecosystem services flow. Acta Ecologica Sinica, 2017, 37(10): 32323242.]

[28] GEIJZENDORFFER I R, MARTÍN-LÓPEZ B, ROCHE P K. Improving the identification of mismatches in ecosystem services assessments. Ecological Indicators, 2015, 52: 320-331.

[29] 黄隆杨, 刘胜华, 方芗, 等. 基于 “质量一风险一需求”框架的武汉市生态安全格局构建. 应用生态学报, 2019, 30(2): 615-626. [HUANG L Y, LIU S H, FANG Y, et al. Construction of Wuhan's ecological security pattern under the "qualityrisk-requirement" framework. Chinese Journal of Applied Ecology, 2019, 30(2): 615-626.] 
[30] 马明, 顾康康, 李咏. 基于生态安全格局的城乡生态空间布局与优化: 以宣城市为例. 中国农业资源与区划, 2019, 40(4): 93-102. [MA M, GU K K, LI Y. Urban and rural ecological space layout and optimization based on ecological security pattern: Taking Xuancheng city as an example. Chinese Journal of Agricultural Resources and Regional Planning, 2019, 40(4): 93-102.]

[31] 蒙吉军, 王雅, 王晓东, 等. 基于最小累积阻力模型的贵阳市景观生态安全格局构建. 长江流域资源与环境, 2016, 25 (7): 1052-1061. [MENG J J, WANG Y, WANG X D, et al. Construction of landscape ecological security pattern in Guiyang based on MCR model. Resources and Environment in the Yangtze Basin, 2016, 25(7): 1052-1061.]

[32] WEI W, CHEN D, WANG L, et al. Global synthesis of the classifications, distributions, benefits and issues of terracing. Earth-Science Reviews, 2016, 159: 388-403.

[33] 郑达贤, 汤小华. 福建省生态功能区划研究. 北京: 中国环境科学出版社, 2007: 41-56. [ZHENG X D, TANG X H. Eco-functional Regionalization of Fujian Province. Beijing: China Environmental Science Press, 2007: 41-56.]

[34] 李波然, 李阳兵, 王永艳, 等. 三峡库区县域景观生态安全格局识别与功能分区: 以奉节县为例. 生态学杂志, 2015, 34(7): 1959-1967. [LI X R, LI Y B, WANG Y Y, et al. Identification of ecological security patterns for county-level landscapes and function division of the Three Gorges Reservoir Area: A case in Fengiie. Chinese Journal of Ecology, 2015, 34(7): 1959-1967.]

[35] 蔡青, 曾光明, 石林, 等. 基于栅格数据和图论算法的生态廊道识别. 地理研究, 2012, 31(8): 1523-1534. [CAI Q, ZENG G M, SHI L, et al. Identifying ecological corridors using shortest path algorithm based on raster data. Geographical Research, 2012, 31(8): 1523-1534.]

[36] 刘慧敏, 范玉龙, 丁圣彦. 生态系统服务流研究进展. 应用生态学报, 2016, 27(7): 2161-2171. [LIU H M, FAN Y L, DING S Y. Research progress of ecosystem service flow. Chinese Journal of Applied Ecology, 2016, 27(7): 2161-2171.]

[37] 杨天荣, 匡文慧, 刘卫东, 等. 基于生态安全格局的关中城市群生态空间结构优化布局. 地理研究, 2017, 36(3): 441452. [YANG T R, KUANG W H, LIU W D, et al. Optimizing the layout of eco-spatial structure in Guanzhong Urban Agglomeration based on the ecological security pattern. Geographical Research, 2017, 36(3): 441-452.]

[38] 朱鹤健. 我国亚热带山地生态系统脆弱区生态恢复的战略思想: 基于长汀水土保持 11 年研究成果. 自然资源学报, 2013, 28(9): 1498-1506. [ZHU H J. Strategies on eco-restoration in the subtropical mountain ecosystem fragility areas, China: Based on the achievement of eleven years' research in Changting county. Journal of Natural Resources, 2013, 28 (9): 1498-1506.]

[39] 池源, 石洪华, 孙景宽, 等. 城镇化背景下海岛资源环境承载力评估. 自然资源学报, 2017, 32(8): 1374-1384. [CHI Y, SHI H H, SUN J K, et al. Evaluation on island resources and environment carrying capacity under the background of urbanization. Journal of Natural Resources, 2017, 32(8): 1374-1384.]

[40] DUCHARDT C J, PORENSKY L M, AUGUSTINE D J, et al. Disturbance shapes avian communities on a grasslandsagebrush ecotone. Ecosphere, 2018, 9(10): e02483, Doi: 10.1002/ecs2.2483.

[41] 陈峰, 李红波, 张安录. 基于生态系统服务的中国陆地生态风险评价. 地理学报, 2019, 74(3): 432-445. [CHEN F, LI H B, ZHANG A L. Ecological risk assessment based on terrestrial ecosystem services in China. Acta Geographica Sinica, 2019, 74(3): 432-445.]

[42] 陶岸君, 王兴平. 面向协同规划的县域空间功能分区实践研究: 以安徽省郎溪县为例. 城市规划, 2016, 40(11): 101112. [TAO A J, WANG X P. Spatial function zoning practice at county level oriented at collaborative planning: A case study of Langxi county, Anhui province. City Planning Review, 2016, 40(11): 101-112.] 


\title{
Optimizing the ecological networks based on the supply and demand of ecosystem services in Xiamen-Zhangzhou-Quanzhou region
}

\author{
HU Qi-yu ${ }^{1,2}$, CHEN Song-lin ${ }^{1,2}$ \\ (1. Provincial Key Lab of Subtropical Resources and Environment of Fujian, Fujian Normal University, \\ Fuzhou 350007, China; 2. Institute of Geography, Fujian Normal University, Fuzhou 350007, China)
}

\begin{abstract}
Coupling the supply and demand of ecosystem service with the security pattern of landscape ecology, and deconstructing the ecological space structure of urban agglomerations are the basis for optimizing the spatial arrangement of agriculture- urban areas- ecology networks. Based on the theory of supply and demand for ecosystem service, ecosystem service supply area was determined by fusing the most important areas of the integrated ecosystem services and the boundaries of the ecological red line, by taking Xiamen-Zhangzhou-Quanzhou Urban Agglomeration in the southeast coast of Fujian province as an example. In combination of natural and economic factors, the consumption pattern can be constructed. The minimum cumulative resistance model was further applied to establish a landscape ecology security pattern in order to identify landscape components, such as demand zones, network of ecological flows, and key nodes. Furthermore, the ecological network space of XiamenZhangzhou- Quanzhou region was reconstructed by utilizing layered overlay analysis. The results showed that: (1) The supply area occupied $41.64 \%$ of the study area, in addition, ecological buffer zones, ecological sensitive zones, and production and living zones accounted for $22.67 \%, 31.58 \%$, and $4.11 \%$, respectively. (2) The source of supply was mainly distributed in the hilly and mountainous areas of the central and western regions, where the low-cost areas of ecosystem service were located. The high-cost areas concentrated in the coastal regions were characterized by an octothorpe shaped distribution pattern. (3) Ecological flow paths were highly meshed. They were mainly composed of forests in the central and western regions, and urban water system, green space systems and surrounding farmland in the eastern coastal areas. Both the type and intensity of the driving factors suggested significant spatial heterogeneity. (4) Constructing an ecological network space optimization layout of "nine zones, four groups, one belt, nine corridors and multi-centers" in the study region was also proposed in this research, so as to coordinate the production-living-ecological function among the region and facilitate the synergetic development of the economic-ecological space.
\end{abstract}

Keywords: ecosystem services; ecological networks; MCR model; Xiamen-Zhangzhou-Quanzhou region 